\title{
Analisis Purwarupa Sistem Otomatisasi Penerang Jalan Untuk Menghemat Daya Listrik
}

\author{
Dania Eridani' ${ }^{1}$, M. Azka Asyauqqi ${ }^{2}$, Agung Budi Prasetijo ${ }^{3}$ \\ 1,2,3 Departemen Teknik Komputer, Universitas Diponegoro, Semarang \\ dania@ce.undip.ac.id ${ }^{1}$ azka_assyauqi@student.ce.undip.ac.id², agungprasetijo@gmail.com³
}

\begin{abstract}
Public street lighting automation is one part of an area or a city development design. The design of public street lightning need to pay attention to several aspects, where one of them is how the public street lighting design is able to save electricity consumption. This research contain several combination of public street light-ing automation designs. It use Arduino Mega 2560 board as the main control board, $K Y$-018 sensor as the sen-sor to detect the environment light intensity, HC-SR501 sensor as the sensor to detect object movement, AC light dimmer as the regulator of the lamp, AC power meter as a measuring device to measure the power consumption of the lamp used. The testing mechanism are consist of testing the input and output components in the system and testing the electricity consumption in the circuit design. The results of the research carried out, showed a comparison of the level of electricity consumption from each series of combinations that can be used as a reference for road lighting development planning.
\end{abstract}

Keywords: AC Power Meter, Arduino Mega 2560, HC-SR501, KY-018, Public Street Lighting Automation

\begin{abstract}
Abstrak
Penerangan jalan umum merupakan salah satu bagian dari perancangan suatu wilayah atupun kota. Perancangan penerangan jalan umum memiliki beberapa aspek yang perlu diperhatikan, dimana salah satunya adalah bagaimana rancangan penerangan jalan umum yang mampu menghemat konsumsi daya listrik. Penelitian ini berisikan beberapa kombinasi otomatisasi penerangan jalan umum menggunakan papan Arduino Mega 2560 untuk papan kontrol utama, sensor KY-018 untuk mendeteksi intensitas cahaya di lingkungan, sen-sor HCSR501 untuk mendeteksi objek, AC light dimmer untuk pengatur keluaran daya lampu, dan AC power meter untuk mengukur daya yang digunakan oleh lampu. Pengujian yang dilakukan termasuk pengujian ter-hadap komponen masukan dan keluaran yang ada di sistem dan pengujian daya listrik yang dikonsumsi oleh rangkaian yang dibuat di dalam penelitian. Hasil penelitian yang dilakukan menunjukkan perbandingan tingkat konsumsi daya listrik dari masing-masing kombinasi logika yang dapat digunakan sebagai referensi perencanaan pembangunan penerangan jalan umum.
\end{abstract}

Kata kunci: AC Power Meter, Arduino Mega 2560, HC-SR501, KY-018, Otomatisasi Penerangan Jalan

\section{PENDAHULUAN}

Persoalan penggunaan energi untuk penerangan jalan umum untuk daerah-daerah di Indonesia masih jauh dari kata hemat. Masih banyak sekali daerah-daerah yang belum bisa dan mampu untuk melakukan penghematan energi listrik khususnya untuk penerangan jalan. Bukannya pemerintah daerah tidak mau melaksanakannya, namun terbentur dengan banyaknya masalah dan kendala yang ada di daerah masing-masing, mulai dari masalah biaya sampai dengan kurangnya inovasi dalam mengatasi masalah tersebut. 
Dana yang dibutuhkan untuk alokasi anggaran penerangan jalan umum mencapai hitungan milyar rupiah [1][2]. Persoalan dalam penggunaan daya khususnya untuk penerangan jalan perlu mendapat perhatian lebih. Pasalnya tidak akan ada satu pun pemerintah daerah yang tidak ingin menghemat penggunaan daya listrik untuk penerangan jalan, dimana jika berhasil dilakukan, dampaknya adalah meningkatnya Pendapatan Asli Daerah (PAD) dan meratanya hasil pembangunan berupa fasilitas penerangan jalan di seluruh wilayah dan pelosok kota atau kabupaten di Indonesia.

Perkembangan teknologi yang ada memungkinkan pengembangan suatu sistem penerangan jalan yang dapat digunakan untuk menghemat daya listrik. Contohnya pada penelitian [3] dan [4] yang memanfaatkan tenaga surya untuk meghasilkan energi listrik yang digunakan pada lampu penerangan sehingga mampu menghemat konsumsi daya litrik. Hal ini juga disebutkan di dalam [5] bahwa penggunaan tenaga surya akan dapat digunakan untuk meghemat biaya yang dibutuhkan untuk alokasi penerangan jalan umum. Beberapa penelitian berfokus pada analisis efiensi penerangan jalan umum pada suatu wilayah [6][7] dan beberapa penelitian berfokus pada desain perancangan jalan umum [8][9][10][11].

Penelitian ini tidak hanya membahas perancangan purwarupa otomatisasi penerangan jalan, namun membahas analisis kombinasi simulasi logika penerangan jalan yang dapat digunakan sebagai referensi perencanaan pembangunan penerangan jalan umum. Sesuai dengan yang disebutkan di dalam [12], lampu LED digunakan sebagai komponen dalam penelitian ini karena terbukti memiliki konsumsi daya listrik yang lebih rendah. Tujuan pembuatan Sistem Otomatisasi Penerangan Jalan ini adalah untuk terciptanya purwarupa penerangan jalan yang berjalan secara efektif dan efisien, sehingga dapat menjadi solusi dalam hal penghematan energi listrik khususnya pada penerangan jalan. Selain itu juga memberikan kontribusi sebagai pemacu perkembangan teknologi di Indonesia dengan adanya teknologi yang bermanfaat bagi masyarakat luas.

\section{METODOLOGI PENELITIAN}

Metode penelitian yang digunakan dalam penelitian ini terdiri dari beberapa tahap, yaitu studi literasi, perancangan sistem, implementasi sistem, pengujian dan analisis sistem. Studi literasi yang digunakan untuk mendapatkan inovasi teknologi yang berkaitan dengan penelitian ini serta mendapatkan kebutuhan fungsional dan non-fungsional sistem. Perancangan sistem digunakan untuk menentukan bagaimana perangkat keras dan perangkat lunak dibangun sesuai dengan tujuan penelitian. Implementasi Sistem digunakan untuk menerapkan hasil rancangan desain perangkat keras dan perangkat lunak dalam bentuk purwarupa sistem otomatisasi. Pengujian dilakukan untuk melihat apakah hasil purwarupa sistem sesuai dengan perancangan. Pengujian sistem terdiri dari pengujian komponen masukan dan komponen keluaran beserta beberapa tipe logika penerangan jalan umum. Analisis sistem digunakan untuk mendapatkan hasil perbandingan 
kombinasi logika yang sudah diimplementasikan dan diujikan untuk mendapatkan referensi kombinasi penerangan jalan.

\subsection{Studi Literasi}

Dalam studi literasi didapatkan kebutuhan fungsional dan nonfungsional dalam membangun sistem. Kebutuhan fungsional sistem yang digunakan adalah:

a. Sistem mampu menyalakan dan mematikan lampu penerangan jalan secara otomatis sesuai dengan intensitas cahaya di sekitar sensor.

b. Sistem mampu mendeteksi penggerakan suatu objek yang terdapat di sekitar menggunakan sensor.

c. Sistem mampu mengatur hidup dan mati ataupun redup dan terangnya penerangan jalan secara otomatis sesuai dengan keadaan yang terdeteksi oleh sensor.

Kebutuhan non-fungsional yang ada di dalam sistem adalah:

a. Sistem menggunakan mikrokontroler ATmega 2560 pada papan Arduino [13] sebagai pusat kendali untuk membaca nilai keluaran sensor.

b. Sistem dijalankan dengan catu daya sebesar 9V dan 1A.

c. Sistem menggunakan AC Light Dimmer Module [11] sebagai pengatur keluaran daya pada lampu.

d. Sistem menggunakan AC Power Meter untuk mengukur keluaran dari lampu seperti voltase, arus listrik, daya listrik, dan pemakaian daya listrik.

e. Sistem menggunakan sensor HC-SR501 [14] untuk mendeteksi gerak dan sensor KY-108 [15] untuk mendeteksi cahaya.

f. Sistem menggunakan bahasa pemrograman $\mathrm{C}$ yang terapkan pada perangkat lunak aplikasi Arduino IDE.

\subsection{Perancangan Sistem}

Prinsip kerja dari sistem yang dirancang adalah sistem dapat melakukan fungsi mendektesi cahaya dan pengerakan, serta mengeluarkan output pada sistem penerangan jalan. Sistem meliputi Mikrokontroler Arduino mega 2560 dan lampu LED. Fungsi otomatisasi pada sistem meliputi mendeteksi cahaya pada lingkungan dan penggerakan pada objek lalu memberikan Keluaran hidup, redup atau mati pada lampu LED sesuai dengan kondisi sekitar pada saat itu.

\subsubsection{Perancangan Perangkat Keras Sistem}

Proses perancangan perangkat keras menjelaskan rancangan perangkat keras yang akan digunakan untuk membangun sistem. Dimulai dari perangkat keras utama hingga perangkat elektronik pendukung sistem. Di dalam penelitian ini, purwarupa yang dibangun terdiri dari 3 titik lampu LED yang digunakan sebagai penerangan jalan, yang digubungkan dengan AC 
Light dimmer sehingga keluaran yang dihasilkan bisa diatur. Gambar 1 merupakan diagram blok perangkat keras.

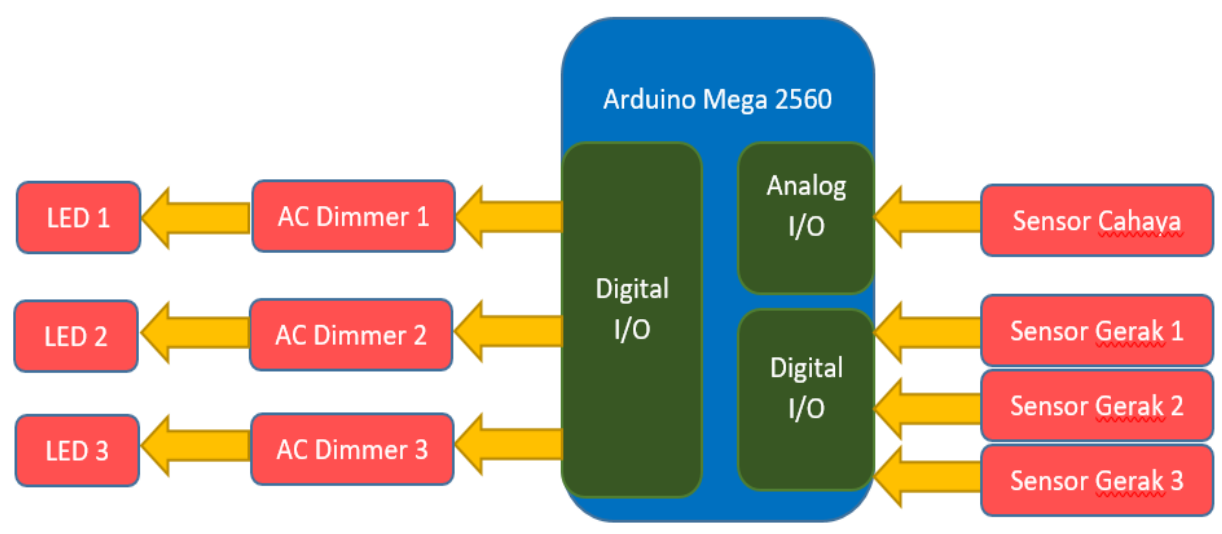

Gambar 1. Diagram Blok Perangkat Keras

Pusat kendali sistem menggunakan papan Arduino Mega 2560 dengan mikrokontroler ATmega 2560. Komponen yang terhubung dengan sistem diantaranya adalah KY-018 sebagai sensor pendeteksi cahaya, HC-SR501 sebagai sensor pendeteksi gerakan, AC Dimmer sebagai pengatur aliran daya pada lampu, dan LED sebagai keluaran berupa cahaya pada lampu. Sistem menggunakan beberapa pin yang tersedia pada papan Arduino Mega 2560. Diantaranya adalah satu pin analog untuk sensor KY-018, 3 pin digital untuk sensor HC-SR501, dan 3 pasang pin digital untuk modul AC Dimmer.

\subsubsection{Perancangan Perangkat Lunak Sistem}

Perancangan perangkat lunak merupakan perancangan program yang dibutuhkan oleh mikrokontroler Arduino Mega 2560 untuk dapat mengendalikan keluaran pada lampu LED sesuai data masukan dari sensor KY-108 dan sensor HC-SR501, agar menjadi sebuah kesatuan sistem penerangan jalan. Gambaran umum dari perangkat lunak yang dikembangkan dapat dilihat pada Gambar 2.

Proses otomatisasi sensor pada void loop memiliki prinsip kerja pemanfaatkan sensor KY-018 sebagai pendeteksi siang atau malam. Ketika intensitas cahaya yang dibaca oleh sensor KY-018 besar maka kondisi yang terbentuk adalah siang hari sehingga semua lampu akan mati, sebaliknya jika intensitas cahaya yang dibaca kecil maka kondisi yang terbentuk adalah malam hari sehingga semua lampu akan hidup sesuai dengan yang di atur. Selanjutnya sensor HC-SR501 sebagai pendeteksi gerakan, dimana setiap ada atau tidaknya pergerakan yang terbaca akan memberikan perintah untuk menghidupkan atau meredupkan lampu. 


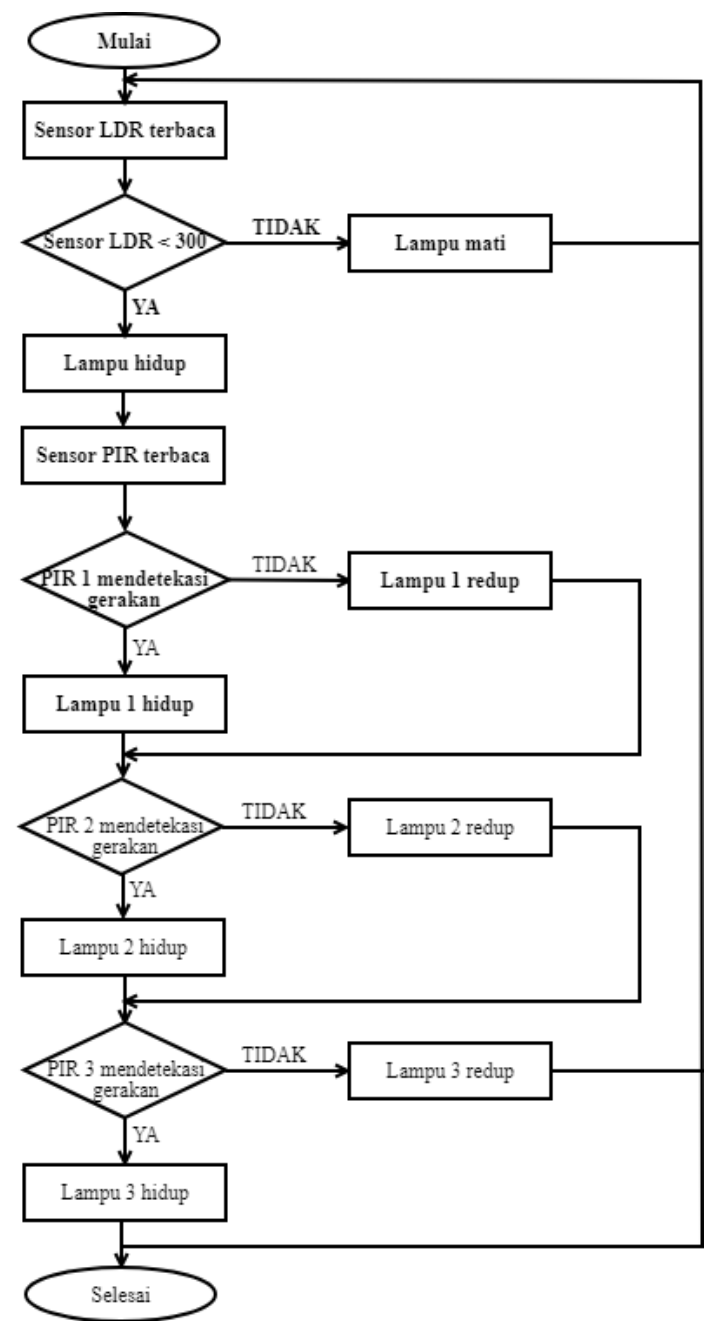

Gambar 2. Diagram Alir Sistem

Diagram alir di atas merupakan desain awal perangkat lunak yang ada di dalam sistem. Namun untuk mendapatkan analisis kombinasi logika yang diharapkan, dalam penelitian ini menerapkan beberapa konsep diagram alir yang berbeda.

\section{HASIL DAN PEMBAHASAN}

Hasil dan pembahasan terdiri dari tiga bagian. Bagian pertama adalah implementasi sistem, bagian kedua adalah pengujian sistem, dan bagian ketiga adalah analisis sistem.

\subsection{Implementasi Sistem}

Perangkat yang diimplementasikan dalam sistem merupakan sebuah purwarupa lampu penerangan jalan umum yang terdiri dari 3 tiang yang terpasang lampu LED dengan masing-masing tiang memiliki sistem sendiri. Pada sistem utama terdapat 3 AC Dimmer dan sebuah Arduino Mega 2560 
sebagai tempat komponen-komponen sistem saling terhubung untuk menjadi sebuah sistem perangkat keras seperti pada Gambar 3.

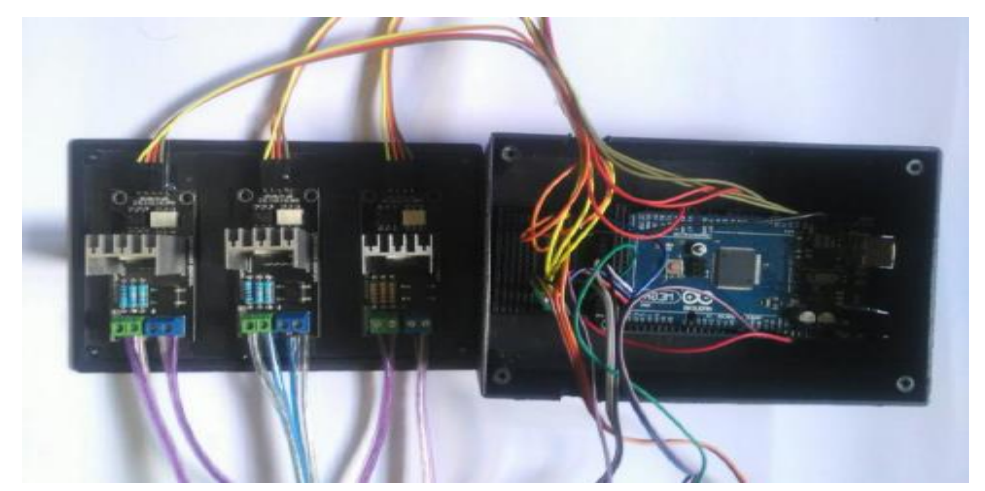

Gambar 3. Sistem Utama Purwarupa Penerangan Jalan

\subsection{Pengujian Sistem}

Pengujian sistem dilakukan dengan pengujian terhadap pembacaan nilai dari masing-masing sensor dan perangkat masukan lainnya. Kemudian dilakukan pengujian terhadap perangkat keluaran sistem yang berupa pengujian energi pada kombinasi logika rangkian.

\subsubsection{Pengujian Perangkat Masukan}

Pengujian pembacaan sensor dilakukan dengan membandingkan sistem dengan alat ukur yang tersedia. Pengujian dibagi menjadi beberapa parameter yang dapat diukur, yaitu pembacaan nilai intensitas cahaya dan gerakan.

\section{a) Sensor Cahaya KY-018}

Sensor KY-018 merupakan sensor yang digunakan untuk mengukur intensitas cahaya. Pengujian sensor ini dilakukan dengan mengukur nilai maksimal dan minimal intensitas cahaya yang di tangkap dalam jangka waktu 24 jam dengan rentang hitung setiap 2 jam dan di tambah 5 menit hitung agar mendapatkan data yang lebih akurat. Gambar 4 merupakan hasil pengujian dari sensor cahaya dalam nilai analog.

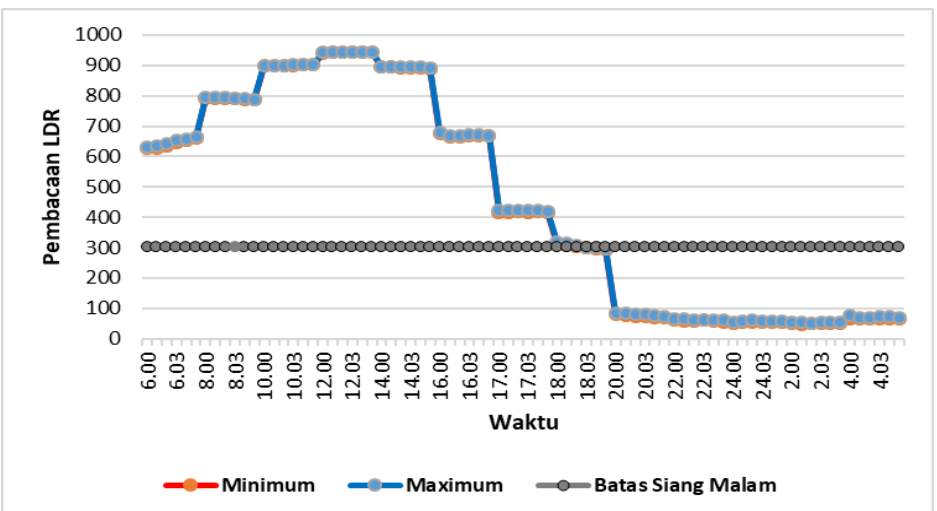

Gambar 4. Hasil Pengujian Sensor Cahaya KY-018 
Dari hasil pengujian juga didapatkan bahwa nilai analog dari intensitas cahaya pada saat jam 18.00 WIB dapat menjadi acuan untuk menentukan batasan siang dan malam yaitu pada nilai 300 .

\section{b) Sensor Gerak HC-SR501}

Sensor HC-SR501 merupakan sensor yang digunakan untuk mendeteksi gerakan manusia atau hewan. Pengujian sensor ini dilakukan dengan melakukan test pembacaan pada sensor gerak berdasarkan jarak radius dan sudut yang telah di tentukan. Sudut dan jarak diatur dari titik sensor berada dengan sumber gerakan. Gambar 5 menunjukkan skenario pengujian sensor gerak HC-SR50.

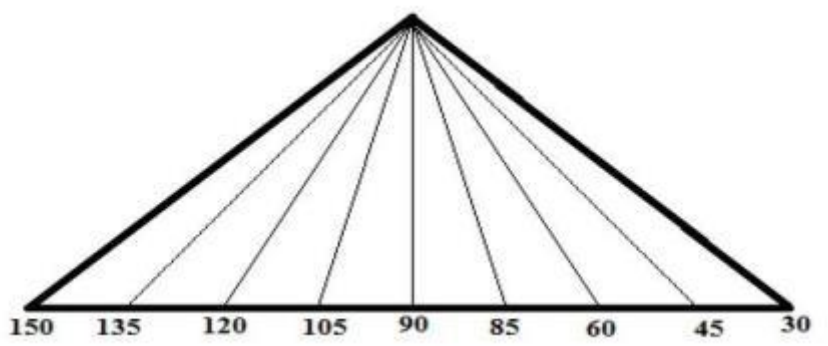

Gambar 5. Skenario Pengujian Sensor Gerak HC-SR50

Tabel 1 menunjukkan bahwa objek yang berada tepat di depan sensor cenderung berhasil di tangkap pergerakannya oleh sensor gerak HC-SR501. Sensor berhasil menangkap pergerakan hingga mencapai jarak $5 \mathrm{~m}$ dengan sudut terluar $30^{\circ}$ dan $150^{\circ}$. Namun pada pembacaan objek pada radius jarak tertentu pada sudut $30^{\circ}$ dan $150^{\circ}$ tidak terjadi pembacaan. Dengan persentase keberhasilan 82,22\% menunjukan sensor dapat di gunakan sebagai pendeteksi pada sistem penerangan jalan.

Tabel 1. Hasil Pengujian Sensor Gerak HC-SR50

\begin{tabular}{|c|c|c|c|c|c|c|c|c|c|}
\hline \multirow{2}{*}{ Jarak (m) } & \multicolumn{10}{|c|}{ Sudut } \\
\cline { 2 - 10 } & $\mathbf{3 0}^{\mathbf{0}}$ & $\mathbf{4 5}^{\mathbf{0}}$ & $\mathbf{6 0}^{\mathbf{0}}$ & $\mathbf{8 5}^{\mathbf{0}}$ & $\mathbf{9 0}^{\mathbf{0}}$ & $\mathbf{1 0 5}^{\mathbf{0}}$ & $\mathbf{1 2 0}^{\mathbf{0}}$ & $\mathbf{1 3 5}^{\mathbf{0}}$ & $\mathbf{1 5 0}^{\mathbf{0}}$ \\
\hline 0,5 & $\sqrt{ }$ & $\sqrt{ }$ & $\sqrt{ }$ & $\sqrt{ }$ & $\sqrt{ }$ & $\sqrt{ }$ & $\sqrt{ }$ & $\sqrt{ }$ & $\sqrt{ }$ \\
\hline 1 & $\sqrt{ }$ & $\sqrt{ }$ & $\sqrt{ }$ & $\sqrt{ }$ & $\sqrt{ }$ & $\sqrt{ }$ & $\sqrt{ }$ & $\sqrt{ }$ & $\sqrt{ }$ \\
\hline 1,5 & $\sqrt{ }$ & $\sqrt{ }$ & $\sqrt{ }$ & $\sqrt{ }$ & $\sqrt{ }$ & $\sqrt{ }$ & $\sqrt{ }$ & $\sqrt{ }$ & $\sqrt{ }$ \\
\hline 2 & $\sqrt{ }$ & $\sqrt{ }$ & $\sqrt{ }$ & $\sqrt{ }$ & $\sqrt{ }$ & $\sqrt{ }$ & $\sqrt{ }$ & $\sqrt{ }$ & - \\
\hline 2,5 & - & $\sqrt{ }$ & $\sqrt{ }$ & $\sqrt{ }$ & $\sqrt{ }$ & $\sqrt{ }$ & $\sqrt{ }$ & $\sqrt{ }$ & - \\
\hline 3 & - & $\sqrt{ }$ & $\sqrt{ }$ & $\sqrt{ }$ & $\sqrt{ }$ & $\sqrt{ }$ & $\sqrt{ }$ & $\sqrt{ }$ & $\sqrt{ }$ \\
\hline 3,5 & - & $\sqrt{ }$ & $\sqrt{ }$ & $\sqrt{ }$ & $\sqrt{ }$ & $\sqrt{ }$ & $\sqrt{ }$ & $\sqrt{ }$ & - \\
\hline 4 & - & $\sqrt{ }$ & $\sqrt{ }$ & $\sqrt{ }$ & $\sqrt{ }$ & $\sqrt{ }$ & $\sqrt{ }$ & $\sqrt{ }$ & - \\
\hline 4,5 & - & $\sqrt{ }$ & - & $\sqrt{ }$ & $\sqrt{ }$ & $\sqrt{ }$ & $\sqrt{ }$ & - & - \\
\hline 5 & - & - & $\sqrt{ }$ & $\sqrt{ }$ & $\sqrt{ }$ & $\sqrt{ }$ & $\sqrt{ }$ & - & - \\
\hline
\end{tabular}

\subsubsection{Pengujian Perangkat Keluaran}

Pengujian perangkat keluaran merupakan pengujian penggunaan daya listrik berdasarkan beberapa skema kombinasi yaitu, pengujian 1 tiang, pengujian 3 tiang, dan pegujian berdasarkan 2 kombinasi. Pengujian ini 
dilakukan dengan mengukur beberapa parameter seperti voltase, arus listrik, daya listrik, dan pemakaian energi listrik menggunakan AC power meter.

\section{a) Pengujian 1 Tiang}

Pengujian ini bertujuan untuk mengukur pemakaian energi pada 1 tiang dengan kondisi lampu nyala terang dan redup. Pengujian dilakukan dengan mengukur beberapa parameter yang telah ditentukan dengan pengambilan data setiap 10menit dalam jangka waktu 1 jam. Tabel 2 dan Tabel 3 merupakan hasil pengujian 1 tiang penyalaan terang dan redup.

Tabel 2. Hasil Pengujian 1 Tiang Redup

\begin{tabular}{|c|c|c|c|c|c|}
\hline \multirow{2}{*}{ Menit } & \multicolumn{5}{|c|}{ 1 Tiang Redup } \\
\cline { 2 - 6 } & $\begin{array}{c}\text { Tegangan } \\
\text { (v) }\end{array}$ & $\begin{array}{c}\text { Arus } \\
\text { Listrik (A) }\end{array}$ & $\begin{array}{c}\text { Faktor } \\
\text { Daya }\end{array}$ & $\begin{array}{c}\text { Daya Listrik } \\
\text { (W) }\end{array}$ & $\begin{array}{c}\text { Pemakaian } \\
\text { Energi Listrik } \\
\text { (KWh) }\end{array}$ \\
\hline 10 & 219,4 & 0,027 & 0,67 & 4,2 & 0 \\
\hline 20 & 218,9 & 0,027 & 0,67 & 4,1 & 0,001 \\
\hline 30 & 218,7 & 0,027 & 0,67 & 4,1 & 0,002 \\
\hline 40 & 220,3 & 0,027 & 0,67 & 4,2 & 0,002 \\
\hline 50 & 220,5 & 0,027 & 0,67 & 4,2 & 0,003 \\
\hline 60 & 220,8 & 0,027 & 0,67 & 4,1 & 0,004 \\
\hline
\end{tabular}

Hasil pengujian pada Tabel 2 menunjukkan bahwa data voltase pada 1 tiang redup berada di rentang nilai $218,7 \mathrm{~V}$ sampai $220,8 \mathrm{~V}$, dan pada Tabel 3 menunjukan bahwa pengujian 1 tiang terang voltase yang didapat berada di rentang nilai $215,0 \mathrm{~V}$ sampai $218,1 \mathrm{~V}$. Hal ini menunjukan hasil dari pengujian voltase tidak jauh berbeda karena sumber yang di gunakan berada pada kisaran 220V.

Tabel 3. Hasil Pengujian 1 Tiang Terang

\begin{tabular}{|c|c|c|c|c|c|}
\hline \multirow{2}{*}{ Menit } & \multicolumn{5}{|c|}{ 1 Tiang Redup } \\
\cline { 2 - 6 } & $\begin{array}{c}\text { Tegangan } \\
\text { (v) }\end{array}$ & $\begin{array}{c}\text { Arus } \\
\text { Listrik (A) }\end{array}$ & $\begin{array}{c}\text { Faktor } \\
\text { Daya }\end{array}$ & $\begin{array}{c}\text { Daya } \\
\text { Listrik (W) }\end{array}$ & $\begin{array}{c}\text { Pemakaian Energi } \\
\text { Listrik (KWh) }\end{array}$ \\
\hline 10 & 215,0 & 0,042 & 0,88 & 8,1 & 0,001 \\
\hline 20 & 217,5 & 0,041 & 0,91 & 8,2 & 0,002 \\
\hline 30 & 215,8 & 0,041 & 0,91 & 8,0 & 0,004 \\
\hline 40 & 218,1 & 0,041 & 0,91 & 8,1 & 0,005 \\
\hline 50 & 217,3 & 0,041 & 0,91 & 8,1 & 0,006 \\
\hline 60 & 215,5 & 0,041 & 0,91 & 8,0 & 0,008 \\
\hline
\end{tabular}

Hasil pengujian arus listrik menunjukkan bahwa data yang didapat konstan pada nilai 0,27 A untuk 1 tiang redup dan berada pada kisaran 0,41A sampai $0,42 \mathrm{~A}$ untuk 1 tiang terang. Perbedaan pemakaian arus listrik dari kedua tiang ini sebesar $0,15 \mathrm{~A}$, dimana tiang redup memiliki persentase $35,71 \%$ lebih hemat dari tiang terang.

Hasil pengujian daya listrik menunjukkan bahwa data yang didapat berada pada nilai $4,1 \mathrm{~W}$ sampai $4,2 \mathrm{~W}$ pada 1 tiang redup dan berada pada 
kisaran 8,0W sampai 8,2W pada 1 tiang terang. Perbedaan daya listrik dari kedua tiang ini sekitar $4 \mathrm{~W}$, dimana tiang redup memiliki persentase daya $49 \%$ lebih kecil dari tiang terang.

Dari total hasil pemakaian energi listrik selama 1 jam, 1 tiang redup memiliki total pemakaian energi sebesar $0,004 \mathrm{KWh}$ dan 1 tiang terang sebesar 0,008KWh. Selain itu, dapat diamati bahwa pemakaian energi pada 1 tiang redup memiliki kenaikan dibawah $0,001 \mathrm{KWh}$ per 10 menit-nya, namun 1 tiang terang memiliki kenaikan sama atau lebih dari $0,001 \mathrm{KWh}$ per 10menit-nya. Dari hal ini dapat disimpulkan bahwa lampu dengan nyala redup memiliki total konsumsi daya 50\% lebih rendah dibandingkan dengan lampu yang menyala terang.

\section{b) Pengujian 3 Tiang}

Pengujian 3 tiang terang dilakukan dengan mengukur beberapa parameter yang telah ditentukan dengan pengambilan data setiap 1jam dengan total waktu 12 jam, dimulai dari pukul 18.00 WIB sampai dengan pukul 06.00 WIB. Tabel 4 merupakan hasil pengujian 3 tiang dengan penyalaan terang.

Hasil pengujian pada Tabel 4 menunjukkan bahwa data voltase 3 tiang terang berada di rentang nilai $210,1 \mathrm{~V}$ sampai $218,9 \mathrm{~V}$. Dalam pengujian ini, nilai voltase yang didapat menunjukkan hasil yang beragam. Namun berdasarkan rentang nilainya, diketahui bahwa data tersebut masih berada pada nilai voltase yang wajar yaitu berkisar $220 \mathrm{~V}$. Pada hasil pengujian arus listrik 3 tiang terang memiliki pemakaian arus listrik berkisar 0,107A sampai $0,109 \mathrm{~A}$. Dengan selisih perbedaan pemakai arus tertinggi dengan terendah yang didapat hanya sebesar 0,002A.

Tabel 4. Hasil Pengujian 3 Tiang Terang

\begin{tabular}{|c|c|c|c|c|c|}
\hline \multirow{2}{*}{ Jam } & \multicolumn{5}{|c|}{ 3 Tiang Terang } \\
\cline { 2 - 6 } & $\begin{array}{c}\text { Tegangan } \\
\text { (v) }\end{array}$ & $\begin{array}{c}\text { Arus Listrik } \\
\text { (A) }\end{array}$ & $\begin{array}{c}\text { Faktor } \\
\text { Daya }\end{array}$ & $\begin{array}{c}\text { Daya Listrik } \\
\text { (W) }\end{array}$ & $\begin{array}{c}\text { Pemakaian Energi } \\
\text { Listrik (KWh) }\end{array}$ \\
\hline 19.00 & 216,8 & 0,109 & 0,84 & 19,6 & 0,020 \\
\hline 20.00 & 216,5 & 0,109 & 0,85 & 19,5 & 0,040 \\
\hline 21.00 & 216,7 & 0,107 & 0,84 & 19,4 & 0,060 \\
\hline 22.00 & 210,9 & 0,107 & 0,84 & 19,4 & 0,079 \\
\hline 23.00 & 210,8 & 0,108 & 0,86 & 19,4 & 0,099 \\
\hline 24.00 & 210,1 & 0,108 & 0,86 & 19,5 & 0,118 \\
\hline 01.00 & 213,7 & 0,107 & 0,84 & 19,3 & 0,137 \\
\hline 02.00 & 214,5 & 0,107 & 0,84 & 19,6 & 0,157 \\
\hline 03.00 & 218,9 & 0,109 & 0,84 & 19,7 & 0,177 \\
\hline 04.00 & 217,2 & 0,109 & 0,84 & 19,6 & 0,197 \\
\hline 05.00 & 216,1 & 0,109 & 0,84 & 19,5 & 0,216 \\
\hline 06.00 & 218,1 & 0,109 & 0,84 & 19,6 & 0,236 \\
\hline
\end{tabular}

Hasil pengujian daya listrik menunjukkan bahwa data yang didapat berada pada nilai 19,3Watt sampai 19,7Watt. Dengan rataan daya listrik yang didapat sebesar 19,5Watt dan selisih perbedaan daya listrik tertinggi dan 
terendah yang didapat sebesar 0,4Watt. Dari total hasil pemakaian energi listrik selama 12 jam, 3 tiang terang memiliki total pemakaian daya sebesar 0,236KWh. Selain itu, dapat diamati bahwa pemakaian energi pada 3 tiang terang memiliki kenaikan 0,019KWh sampai 0,020KWh per 1 jam.

Tabel 5. Hasil Pengujian 3 Tiang Redup

\begin{tabular}{|c|c|c|c|c|c|}
\hline \multirow{2}{*}{ Jam } & \multicolumn{5}{|c|}{ 3 Tiang Redup } \\
\cline { 2 - 6 } & $\begin{array}{c}\text { Tegangan } \\
\text { (v) }\end{array}$ & $\begin{array}{c}\text { Arus } \\
\text { Listrik (A) }\end{array}$ & $\begin{array}{c}\text { Faktor } \\
\text { Daya }\end{array}$ & $\begin{array}{c}\text { Daya } \\
\text { Listrik (W) }\end{array}$ & $\begin{array}{c}\text { Pemakaian Energi } \\
\text { Listrik (KWh) }\end{array}$ \\
\hline 19.00 & 214,4 & 0,069 & 0,48 & 7,2 & 0,007 \\
\hline 20.00 & 215,5 & 0,070 & 0,47 & 7,3 & 0,013 \\
\hline 21.00 & 216,7 & 0,069 & 0,48 & 7,3 & 0,020 \\
\hline 22.00 & 220,8 & 0,069 & 0,48 & 7,4 & 0,028 \\
\hline 23.00 & 223,3 & 0,069 & 0,48 & 7,5 & 0,035 \\
\hline 24.00 & 222,8 & 0,068 & 0,49 & 7,5 & 0,042 \\
\hline 01.00 & 224,9 & 0,068 & 0,49 & 7,5 & 0,049 \\
\hline 02.00 & 226,0 & 0,068 & 0,49 & 7,5 & 0,057 \\
\hline 03.00 & 224,5 & 0,068 & 0,49 & 7,4 & 0,064 \\
\hline 04.00 & 223,6 & 0,067 & 0,49 & 7,4 & 0,072 \\
\hline 05.00 & 225,2 & 0,068 & 0,47 & 7,5 & 0,079 \\
\hline 06.00 & 222,5 & 0,069 & 0,48 & 7,4 & 0,086 \\
\hline
\end{tabular}

Tabel 5 merupakan hasil pengujian 3 tiang dengan penyalaan redup. Hasil pengujian pada Tabel 5 menunjukkan bahwa data voltase 3 tiang redup berada di rentang nilai $214,4 \mathrm{~V}$ sampai $226,0 \mathrm{~V}$. Dalam pengujian ini, nilai voltase yang didapat menunjukkan hasil yang beragam. Namun berdasarkan rentang nilainya, diketahui bahwa data tersebut masih berada pada nilai voltase yang wajar yaitu berkisar 220V.

Pada hasil pengujian arus listrik, 3 tiang redup memiliki pemakaian arus listrik berkisar 0,068A sampai 0,070A, sedangkan 3 tiang terang memiliki pemakaian arus listrik dalam kisaran 0,107A sampai 0,109A. Dengan selisih pemakaian arus sebesar 0,039A, didapatkan hasil bahwa 3 tiang redup memiliki persentase pemakaian arus listrik 36,11\% lebih rendah dibandingkan dengan pemakaian arus 3 tiang terang.

Hasil pengujian daya listrik menunjukkan bahwa data yang didapat berada pada nilai 7,2Watt sampai 7,5Watt di bandingkan dengan daya listrik yang didapat pada 3 tiang terang berada pada kisaran 19,3Watt sampai 19,7Watt. Perbedaan daya listrik dari kedua tiang ini sekitar 12,15Watt, dimana 3 tiang redup memiliki persentase daya listrik 61,7\% lebih kecil dari 3 tiang terang.

\section{c) Pengujian Kombinasi}

Pengujian dilakukan dengan mengukur pemakaian energi listrik pada 3 tiang dengan kombinasi lampu nyala terang, mati dan redup. Tujuan dibuatnya 3 tiang dengan kombinasi ini adalah untuk mendapatkan sistem penerangan jalan yang dapat melakukan penyalaan lampu yang lebih efisien dengan mengkombinasikan penyalaan mati, redup dan terang serta dapat 
mengatur penyalaan lampu secara otomatis sesuai dengan kondisi keadaan sekitar.

Kombinasi 1 memiliki sistem kerja ketika sensor cahaya KY-018 mendeteksi adanya perubahan kondisi dari siang menjadi malam, tiang 1 dan tiang 3 berada pada kondisi awal nyala terang dan tiang 2 berada pada kondisi mati. Setiap pergerakan yang terdeteksi oleh sensor gerak HC-SR501 membuat tiang 2 otomatis akan berubah menjadi terang.

Kombinasi 2 memiliki sistem kerja ketika sensor cahaya KY-018 mendeteksi adanya perubahan kondisi dari siang menjadi malam, secara otomatis tiang 1, tiang 2 , dan tiang 3 berada pada kondisi awal nyala redup. Setiap deteksi gerakan oleh sensor gerak HC-SR501 yang berada pada tiap tiang akan membuat lampu pada tiang tersebut otomatis berubah menjadi terang.

Pengujian dilakukan dengan mengukur beberapa parameter yang telah ditentukan. Pengambilan data dilakukan setiap 1 jam dengan total waktu 12 jam. Dari pukul 18.00 WIB sampai dengan pukul 22.00 WIB diasumsikan sebagai waktu sibuk, perubahan kondisi pada lampu dari mati ke terang ataupun redup ke terang dan sebaliknya akan banyak terjadi. Pada pukul 22.00 WIB sampai dengan pukul 01.00 WIB diasumsikan keadaan sekitar normal, perubahan kondisi hanya terjadi sesekali pada lampu. Dari pukul 01.00 WIB sampai dengan pukul 06.00 tidak banyak perubahan kondisi yang terjadi pada lampu karena diasumsikan keadaan sekitar yang telah sepi. Tabel 6 dan table 7 merupakan hasil pengujian 3 tiang dengan kombinasi yang dirancang.

Tabel 6. Hasil Pengujian Kombinasi 1

\begin{tabular}{|c|c|c|c|c|c|}
\hline \multirow{2}{*}{ Jam } & \multicolumn{5}{|c|}{ Kombinasi 1 } \\
\cline { 2 - 6 } & $\begin{array}{c}\text { Tegangan } \\
\text { (v) }\end{array}$ & $\begin{array}{c}\text { Arus } \\
\text { Listrik (A) }\end{array}$ & $\begin{array}{c}\text { Faktor } \\
\text { Daya }\end{array}$ & $\begin{array}{c}\text { Daya } \\
\text { Listrik (W) }\end{array}$ & $\begin{array}{c}\text { Pemakaian Energi } \\
\text { Listrik (KWh) }\end{array}$ \\
\hline 19.00 & 214,8 & 0,109 & 0,84 & 19,6 & 0,020 \\
\hline 20.00 & 219,1 & 0,109 & 0,84 & 19,9 & 0,040 \\
\hline 21.00 & 218,2 & 0,109 & 0,84 & 19,9 & 0,059 \\
\hline 22.00 & 215,1 & 0,109 & 0,84 & 19,5 & 0,079 \\
\hline 23.00 & 220,9 & 0,075 & 0,84 & 14,1 & 0,093 \\
\hline 24.00 & 216,9 & 0,075 & 0,86 & 13,9 & 0,108 \\
\hline 01.00 & 220,8 & 0,075 & 0,84 & 14,0 & 0,122 \\
\hline 02.00 & 219,4 & 0,075 & 0,84 & 14,0 & 0,137 \\
\hline 03.00 & 217,0 & 0,075 & 0,84 & 13,9 & 0,151 \\
\hline 04.00 & 215,0 & 0,076 & 0,85 & 13,8 & 0,164 \\
\hline 05.00 & 216,2 & 0,075 & 0,86 & 13,9 & 0,178 \\
\hline 06.00 & 217,8 & 0,075 & 0,86 & 14,0 & 0,192 \\
\hline
\end{tabular}

Tabel 7. Hasil Pengujian Kombinasi 2

\begin{tabular}{|c|c|c|c|c|c|}
\hline \multirow{2}{*}{ Jam } & \multicolumn{5}{|c|}{ Kombinasi 2 } \\
\cline { 2 - 6 } & $\begin{array}{c}\text { Tegangan } \\
\text { (v) }\end{array}$ & $\begin{array}{c}\text { Arus } \\
\text { Listrik (A) }\end{array}$ & $\begin{array}{c}\text { Faktor } \\
\text { Daya }\end{array}$ & $\begin{array}{c}\text { Daya } \\
\text { Listrik (W) }\end{array}$ & $\begin{array}{c}\text { Pemakaian Energi } \\
\text { Listrik (KWh) }\end{array}$ \\
\hline 19.00 & 211,6 & 0,107 & 0,85 & 19,3 & 0,019 \\
\hline 20.00 & 212,8 & 0,107 & 0,85 & 19,1 & 0,038 \\
\hline
\end{tabular}




\begin{tabular}{|c|c|c|c|c|c|}
\hline \multirow{2}{*}{ Jam } & \multicolumn{5}{|c|}{ Kombinasi 2 } \\
\cline { 2 - 6 } & $\begin{array}{c}\text { Tegangan } \\
\text { (v) }\end{array}$ & $\begin{array}{c}\text { Arus } \\
\text { Listrik (A) }\end{array}$ & $\begin{array}{c}\text { Faktor } \\
\text { Daya }\end{array}$ & $\begin{array}{c}\text { Daya } \\
\text { Listrik (W) }\end{array}$ & $\begin{array}{c}\text { Pemakaian Energi } \\
\text { Listrik (KWh) }\end{array}$ \\
\hline 21.00 & 216,2 & 0,107 & 0,85 & 19,5 & 0,057 \\
\hline 22.00 & 217,1 & 0,106 & 0,85 & 19,6 & 0,077 \\
\hline 23.00 & 219,3 & 0,069 & 0,48 & 7,3 & 0,085 \\
\hline 24.00 & 218,3 & 0,069 & 0,48 & 7,4 & 0,094 \\
\hline 01.00 & 217,2 & 0,069 & 0,48 & 7,3 & 0,101 \\
\hline 02.00 & 215 & 0,069 & 0,48 & 7,3 & 0,108 \\
\hline 03.00 & 218,6 & 0,069 & 0,48 & 7,3 & 0,116 \\
\hline 04.00 & 221,2 & 0,069 & 0,48 & 7,3 & 0,124 \\
\hline 05.00 & 221,3 & 0,069 & 0,48 & 7,5 & 0,131 \\
\hline 06.00 & 220,3 & 0,070 & 0,47 & 7,5 & 0,138 \\
\hline
\end{tabular}

Hasil pengujian pada Tabel 6 dan Tabel 7 menunjukkan bahwa data voltase pada kombinasi 1 berada di rentang nilai 214,8 sampai 220 ,9, dan pada kombinasi 2 voltase yang didapat berada di rentang nilai 211,6 sampai 221,3 . Hal ini menunjukan bahwa hasil pengujian kedua kombinasi tersebut berada pada voltase yang benar yakni pada kisaran $220 \mathrm{~V}$.

Pada pengujian arus listrik kombinasi 1, empat jam pertama didapatkan nilai arus listrik 0,109A dan delapan jam selanjutnya didapatkan arus listrik pada kisaran 0,075 sampai 0,076. Sedangkan pada kombinasi 2, empat jam pertama didapatkan nilai arus 0,106 sampai 0,107 dan delapan jam selanjutnya arus listrik berada di rentang 0,069 sampai 0,070. Dari hasil pengujian ini diketahui bahwa pada jam sibuk, arus listrik yang digunakan lebih banyak dibanding dengan penggunaan arus listrik pada jam normal dan sepi. Pada jam sibuk, arus yang digunakan di kombinasi 2 berada pada arus yang lebih rendah yakni 0,107A dibanding 0,109A pada kombinasi 1 . Selain itu selisih pemakaian arus pada waktu sibuk dan jam normal di kombinasi 2 lebih besar dibanding selisih pada kombinasi 1 dimana pada kombinasi 2 memiliki selisih 0,037A dan pada kombinasi 1 memiliki selisih 0,034A. Dari hal ini dapat disimpulkan bahwa kombinasi 2 memiliki pemakaian arus yang lebih sedikit dibandingkan dengan kombinasi 1.

Hasil pengujian daya listrik di kombinasi 1 menujukkan bahwa empat jam pertama daya listrik yang didapat sebesar 19,5Watt sampai 19,9Watt dan delapan jam selanjutnya daya listrik berada pada kisaran 13,8Watt sampai 14,1Watt. Sedangkan pada kombinasi 2, empat jam pertama didapatkan daya listrik sebesar 19,1Watt sampai 19,6Watt dan delapan jam selanjutnya berada di rentang 7,3Watt sampai 7,5Watt. Dari hasil pengujian ini diketahui bahwa daya listrik pada jam sibuk lebih besar dibandingkan dengan daya listrik pada jam normal dan sepi. Pada kombinasi 2 daya listrik pada waktu sibuk dan jam normal memiliki selisih yang lebih besar dibanding selisih pada kombinasi 1, dimana pada kombinasi 2 memiliki selisih 11,9Watt dan pada kombinasi 1 memiliki selisih 5,7Watt. Dari hal ini dapat disimpulkan bahwa kombinasi 2 memiliki daya listrik yang lebih kecil dibandingkan dengan kombinasi 1. 
Dari total hasil pemakaian daya listrik selama 12 jam, kombinasi 1 memiliki total pemakaian energi sebesar 0,192KWh dan kombinasi 2 sebesar $0,138 \mathrm{KWh}$. Kombinasi 1 memiliki kenaikan pemakaian energi sebesar $0,019 \mathrm{KWh}$ sampai $0,020 \mathrm{KWh}$ pada jam sibuk dan kenaikan $0,014 \mathrm{KWh}$ sampai $0,015 \mathrm{KWh}$ pada jam normal dan sepi. Sebaliknya pada kombinasi 2, kenaikan pemakaian energi pada jam sibuk sebesar 0,019KWh sampai $0,020 \mathrm{KWh}$ serta pada jam normal dan sepi memiliki kenaikan pemakaian energi sebesar 0,007KWh sampai 0,008KWh. Dari hal ini dapat disimpulkan bahwa pengujian kombinasi 2 memiliki pemakaian energi $28,12 \%$ lebih hemat dibandingkan pengujian kombinasi 1.

Hasil pengujian energi pada 3 tiang dapat di tarik kesimpulan bahwa 3 tiang terang memiliki pemakaian energi paling besar dengan total pemakaian sebesar 0,236KWh. Hasil pemakaian energi listrik 3 tiang redup memiliki total pemakaian sebesar $0,086 \mathrm{KWh}$ dan merupakan yang paling rendah di antara semuanya, dengan konsumsi daya 63,55 \% lebih rendah dibandingkan 3 tiang terang, 55,20\% lebih rendah dari kombinasi 1, dan 37,68\% lebih rendah dari kombinasi 2. Kombinasi 1 memiliki persentase total pemakaian hanya 18,64\% lebih hemat dari 3 tiang terang sedangkan kombinasi 2 memiliki persentase total pemakaian energi sebesar $41,53 \%$ lebih hemat dari 3 tiang terang. Gambar 6 merupakan grafik perbandingan pemakaian energi listrik pada 3 tiang.

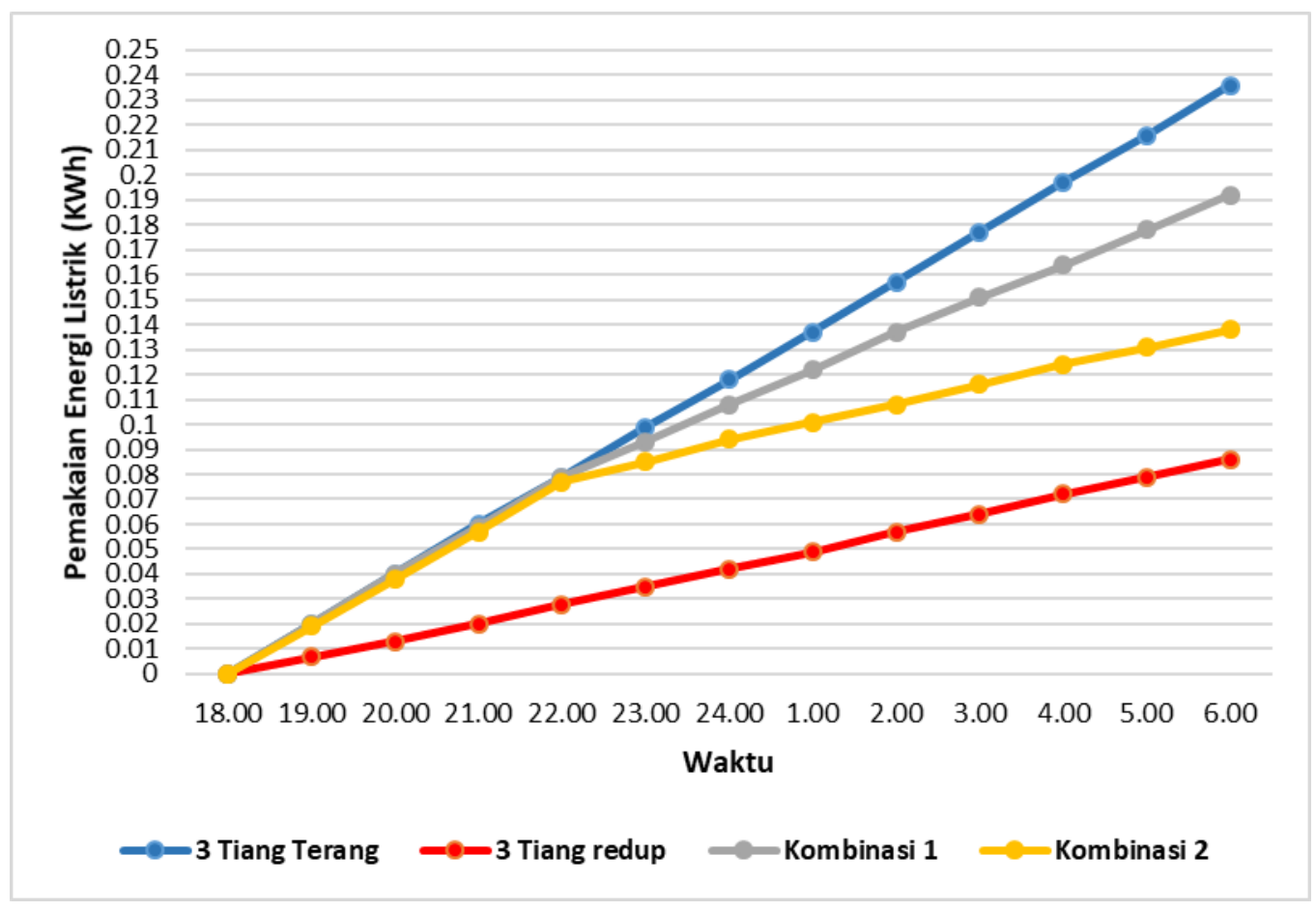

Gambar 6. Grafik Perbandingan Kombinasi 3 Tiang 


\section{SIMPULAN}

Purwarupa penerangan jalan yang dibangun telah berhasil berjalan dan dapat memberikan referensi pemakaian daya listrik dari beberapa kombinasi logika yang ditanamkan ke dalam sistem. Sistem mampu mendeteksi pergerakan hingga mencapai jarak 5 meter dengan sudut terluar $30^{\circ}$ dan $150^{\circ}$ dengan persentase keberhasilan pembacaan mencapai 82,22\%. Sistem mampu mengatur penyalaan pada lampu sesuai dengan yang diinginkan seperti terang, redup dan mati.

Hasil pengujian energi listrik pada 1 tiang terang dan 1 tiang redup di dapatkan bahwa lampu dengan nyala redup memiliki total pemakaian energi $50 \%$ lebih hemat di bandingkan dengan lampu yang menyala terang. Berdasarkan data hasil total pemakaian energi listrik pada 3 tiang redup sebesar 0,086KWh di bandingkan dengan pemakaian energi listrik 3 tiang terang sebesar 0,236 KWh dapat disimpulkan bahwa lampu dengan 3 nyala redup memiliki total konsumsi energi 63,55\% lebih rendah dari 3 lampu dengan penyalaan terang. Berdasarkan hasil pengujian energi pada kombinasi 1 didapatkan persentase total pemakaian hanya 18,64\% lebih hemat dari 3 tiang terang sedangkan kombinasi 2 memiliki persentase total pemakaian energi sebesar 41,53\% lebih hemat dari 3 tiang terang.

\section{DAFTAR PUSTAKA}

[1] M. I. Baktora, "Biaya Listrik PJU Tembus Rp 3,5 Miliar," Nov-2018.

[2] Y. Asyari, "Tagihan PJU Bengkak Rp 11 Miliar, Dishub Ganti Sistem Pembayaran," Feb-2017.

[3] F. Supegina and Imam, "Pengaturan lampu taman led rgb berbasis arduino yang dilengkapi solar cell," Sinergi, vol. 18, no. 1, pp. 9-14, 2014.

[4] A. Di, A. Pendopo, D. A. N. Lapangan, D. T. B. Sihombing, I. Surya, and T. Kasim, "Perencanaan Sistem Penerangan Jalan Umum Dan Taman Di Area Kampus Usu Dengan Menggunakan Teknologi Tenaga Surya (Aplikasi Di Areal Pendopo Dan Lapangan Parkir)," Singuda Ensikom, pp. 118-123, 2013.

[5] Kontan, "ESDM klaim PJU-TS 2019 mampu hemat biaya konsumsi listrik sekitar Rp 7,8 miliar," Apr-2019.

[6] A. Berlian et al., "Analisis Potensi Penghematan Energi Penerangan Jalan Umum Kota Surakarta dan Kota Bandung," vol. 13, no. 1, pp. 1-14, 2014.

[7] A. F. Irawan, Moch. Dhofir, and S. Hadi, "Analisis Peningkatan Efisiensi Penerangan Jalan Umum (PJU) di Kabupaten Jember," J. Mhs. Teub, Vol 2 No. 1, pp. 1-7, 2014.

[8] M. Indriawan, F. Fransisca, and D. Renaldi, "Perancangan Alat Lampu Dengan Sistem Sleep," J. Sisfokom (Sistem Inf. dan Komputer), vol. 4, no. 1, p. 7, 2015.

[9] A. Sędziwy, "Sustainable Street Lighting Design Supported by HypergraphBased Computational Model," Sustain., vol. 8, no. 1, pp. 1-13, 2016.

[10] S. S. Sutono, "Perancangan Sistem Aplikasi Otomatisasi Lampu Penerangan Menggunakan Sensor Gerak dan Sensor Cahaya Berbasis Arduino Uno (Atmega 328)," Maj. IIm. UNIKOM, vol. 12, no. 2, pp. 223-232, 2015.

[11] H. Herlan and B. A. Prabowo, "Rangkaian Dimmer Pengatur Iluminasi Lampu Pijar Berbasis Internally Triggered TRIAC," INKOM J. Informatics, Control Syst. Comput., vol. 3, no. 1, pp. 14-21, 2009. 
Jurnal Sains Komputer \& Informatika (J-SAKTI) Volume 4 Nomor 1 Maret 2020, pp. 142-156 ISSN: 2548-9771/EISSN: 2549-7200

http://tunasbangsa.ac.id/ejurnal/index.php/jsakti

[12] K. Ahadi, M. I. Al Irsyad, and T. Anggono, "Simulasi Potensi Penghematan Energi Listrik pada Penerangan Jalan Umum dengan menggunakan Teknologi Lampu LED," Ketenagalistrikan dan Energi Terbarukan, vol. 17, no. 1, pp. 3142, 2018.

[13] Robotshop, “Arduino Mega 2560," Retrieved Novemb., p. 2560, 2011.

[14] "PIR Sensor (HC-SR501).”.

[15] S. R. I. Supatmi, "PENGARUH SENSOR LDR TERHADAP PENGONTROLAN LAMPU," Maj. Ilm. UNIKOM, vol. 8, no. 2, pp. 175-180. 